BOGDAN KOSZEL

Uniwersytet im. Adama Mickiewicza w Poznaniu

DOI : 10.14746/rie.2016.10.9

\title{
Unia Europejska, Niemcy i problem uchodźców (2014-2016) 1
}

Kwestia pomocy ludziom dotkniętym kataklizmem wojennym, prześladowaniami na tle politycznym, religijnym i etnicznym od początku istnienia Wspólnot Europejskich należała do podstawowego kanonu wartości, którymi kierowały się one w polityce wewnętrznej. Po powstaniu Unii Europejskiej w traktacie z Amsterdamu z 1997 r. rzucone zostało hasło budowy ,przestrzeni wolności, bezpieczeństwa i sprawiedliwości”, gdzie sprawy azylu i uchodźstwa zostały szczególnie wyeksponowane. Na posiedzeniu Rady Europejskiej 15-16 października 1999 r. w Tampere w ramach polityki azylowej i migracyjnej postanowiono utworzyć Wspólny Europejski System Azylowy i kontrolować masowe ruchy migracyjne (Posiedzenie Rady Europejskiej w Tampere, 1999).

W kolejnych latach aktywność Komisji Europejskiej skoncentrowana została na wzmocnieniu współpracy państw unijnych w polityce azylowej i imigracyjnej UE oraz zwiększeniu ochrony granic zewnętrznych Wspólnoty. Zwracano uwagę na integrację imigrantów ze społeczeństwami państw przyjmujących oraz współpracę z krajami ich pochodzenia. Prace nabrały większej dynamiki po zamachach terrorystycznych na USA w 2001 r. Przyspieszono wdrażanie Systemu Informacyjnego Schengen II i uruchomiono system kontroli wydawania wiz o nazwie VIS. Już w grudniu 2000 r. weszło w życie rozporządzenie umożliwiające rozpoczęcie prac w ramach Eurodac, którego zadaniem było wskazanie państwa właściwego do badania wniosków o azyl wniesionych w państwie członkowskim UE, zgodnie z przepisami konwencji dublińskiej oraz w celu ułatwienia stosowania tej konwencji. W 2003 r. została ona zastapiona przez rozporządzenie Dublin II, które z kolei w zmodyfikowanej formie jako rozporządzenie Dublin III weszło w życie z dniem 1 stycznia 2014 r. Na jego podstawie m.in. cudzoziemcy mieli być zawracani do krajów odpowiedzialnych za rozpatrzenie ich wniosków uchodźczych. Regulacje te dotyczyły wszystkich państw członkowskich Unii Europejskiej oraz Norwegii, Szwajcarii, Islandii i Lichtensteinu (Rozporządzenie Parlamentu Europejskiego i Rady, 2013).

Na szczycie Rady Europejskiej 4-5 listopada 2004 r. w Brukseli zatwierdzono wieloletni Program Haski, który był kontynuacją programu z Tampere. W celu jego realizacji Rada Europejska wezwała Komisję do przedstawienia Radzie planu działań, w którym cele i priorytety programu będą przełożone na konkretne działania. Zakładano przejście do drugiej fazy tworzenia systemu, mającego doprowadzić do ustanowienia wspólnej procedury azylowej i jednolitego statusu osób, którym nadano status uchodźcy lub udzielono ochrony uzupełniającej (Program haski, 2005).

${ }^{1}$ Artykuł wykonano w ramach projektu badawczego Narodowego Centrum Nauki Rola Niemiec w procesach decyzyjnych Unii Europejskiej w XXI w., UMO-2014/15/B/HS5/00723. 
Choć nie wszystkie założenia zostały zrealizowane, to jednak udało się powołać do życia w 2005 r. wspólną agencję do zarządzania współpracą operacyjną na granicach zewnętrznych UE (Frontex). Decyzją Parlamentu Europejskiego i Rady z 23 maja 2007 r. ustanowiono Europejski Fundusz na rzecz Uchodźców na lata 2008-2013 jako część programu ogólnego Solidarność i zarządzanie przepływami migracyjnymi. W Europejskim Pakcie o Imigracji i Azylu, zatwierdzonym przez Radę w dniu 25 września 2008 r. i przyjętym przez Radę Europejską na posiedzeniu w dniach 15 i 16 października 2008 r., sformułowano pięć podstawowych zobowiązań dla Unii Europejskiej, wśród których znalazło się budowanie Europy będącej miejscem azylu („Europy azylu"). Na liście tej znalazło się: organizowanie legalnej imigracji, biorąc pod uwagę priorytety, potrzeby i zdolności przyjmowania określone przez każde państwo członkowskie, i sprzyjanie integracji; zwalczanie nielegalnej imigracji, zwłaszcza poprzez zapewnienie powrotów cudzoziemców przebywających nielegalnie do państw pochodzenia lub tranzytu; zwiększenie skuteczności kontroli granicznych; budowa Europy, która będzie miejscem azylu; stworzenie globalnego partnerstwa z państwami pochodzenia i tranzytu przez sprzyjanie synergiom między migracją a rozwojem (Europejski Pakt, 2008).

Zgodnie z przyjętym harmonogramem agendy z Tampere i Programu Haskiego, kolejnego bilansu dokonano w 2009 r. i on ujrzał światło dzienne w postaci Programu Sztokholmskiego. Wiązało się to z prezydencją Szwecji w Radzie UE, która przypadła na drugą połowę 2009 r. W wyniku nieformalnych spotkań ministrów spraw wewnętrznych i ministrów sprawiedliwości państw unijnych w tym samym roku 15-17 lipca w Sztokholmie i 1 października w Hadze powstał 82-stronicowy dokument. Po zasięgnięciu opinii Parlamentu Europejskiego, który w rezolucji z 25 listopada wyraził aprobatę dla głównych założeń Programu Sztokholmskiego, i przyjęciu ostatecznej wersji przygotowanej przez prezydencję, tekst trafił już bezpośrednio na szczebel negocjacji ministerialnych. Ministrowie spraw wewnętrznych i sprawiedliwości, na posiedzeniu Rady UE w dniach 30 listopada i 1 grudnia 2009 r., po dyskusji nad projektem i wprowadzeniu zmian skierowali go na posiedzenie Rady Europejskiej (Gruszczak, 2010).

Program sztokholmski „Otwarta i bezpieczna Europa dla dobra i ochrony obywateli” określał priorytety Unii Europejskiej na lata 2010-2014. Aby zapewnić bezpieczna Europę opartą na poszanowaniu podstawowych praw i wolności obywateli, Program Sztokholmski skoncentrował się na kilku priorytetach. Dwa z nich związane były z problematyką imigracyjną i azylem. „Dostęp do Europy” zapowiadał dalsze rozwijanie polityki dotyczącej zintegrowanego zarządzania granicami i politykę wizową, aby skutecznie zapewniać obywatelom państw trzecich legalny dostęp do Europy, gwarantując jednocześnie bezpieczeństwo swoim własnym obywatelom. „Europa solidarności” wskazywała na konieczność opracowania kompleksowej i elastycznej polityki migracyjnej w oparciu o europejski pakt o imigracji i azylu, gdzie pierwszoplanową rolę odgrywałoby stworzenie do 2012 r. wspólnego europejskiego systemu azylowego (CEAS) (Program sztokholmski, 2010).

Celem pierwszego etapu budowy CEAS w latach 1999-2004 była harmonizacja ram prawnych obowiązujących w państwach członkowskich w dziedzinie azylu na podstawie wspólnych norm minimalnych. Celem drugiego etapu (2009-2013) było 
utworzenie wspólnej procedury azylowej oraz jednolitego statusu ochrony. Propozycje nowych aktów zostały uzupełnione inicjatywami dotyczącymi praktycznej współpracy, solidarności oraz zewnętrznego wymiaru azylu i migracji. Na CEAS złożyło się pięć aktów prawnych: dyrektywa recepcyjna, dyrektywa proceduralna, dyrektywa kwalifikacyjna oraz rozporządzenia Dublin III i Eurodac (Wspólny Europejski System Azylowy, 2014).

Wprawdzie wspólny system europejskiego azylu został opracowany, ale podstawową słabością unijnej współpracy jest współpraca odpowiednich służb w celu likwidacji zagrożeń terrorystycznych w obliczu zmasowanego napływu emigrantów. 24 marca 2016 r. na spotkaniu ministrów spraw wewnętrznych w Brukseli przewodniczący Komisji Europejskiej Jean-Claude Juncker zaapelował o utworzenie unii bezpieczeństwa, ale państwa członkowskie niechętnie godzą się na udostępnianie posiadanych przez siebie informacji. Zwolennicy federalizacji przekonują do utworzenia unijnej agencji ds. bezpieczeństwa, ale jej przeciwnicy argumentują że łatwo może dojść do wycieku wspólnych danych. W efekcie np. włoskie służby bliżej współpracują z USA, Izraelem czy Egiptem niż z wieloma innymi państwami UE. Oceniane najlepiej pod kątem inwigilacji elektronicznej służby Wielkiej Brytanii i Francji rzadko współpracują ze swoimi odpowiednikami z Niemiec, gdzie rygorystycznie przestrzegane są reguły ochrony prywatności i danych osobowych. Inna część państw unijnych z kolei narzeka na niedoinwestowanie i brak możliwości do szerszego operacyjnego działania (Unia radzi o bezpieczeństwie, 2016).

Największe wyzwanie dla polityki wewnętrznej Unii Europejskiej przyniósł kryzys imigracyjny, którego apogeum przypadło na rok 2015 i pierwsze miesiące roku 2016. W wyniku rewolucji arabskich w Afryce Północnej w 2011 r. doszło do obalenia tamtejszych dyktatur i zapoczątkowania procesu przemian politycznych i ustrojowych. Wojna domowa rozgorzała w Libii i w Syrii, gdzie opozycja podjęła walkę z reżimem Baszara al.-Asada. Eskalacja konfliktu w Syrii i obawa przed Państwem Islamskim oznaczały przymusowy pobór do wojska i brak jakichkolwiek perspektyw na stabilizację. W efekcie doszło do pogorszenia się sytuacji w obozach dla uchodźców w Libanie i Turcji. Bardzo szybko też nastąpiła profesjonalizacja grup przestępczych specjalizujących się w przemycie ludzi tzw. szlakiem bałkańsko-śródziemnomorskim (Gebauer, Salloum, 2015).

Tysiące uchodźców z Syrii wspierane falą emigracyjną z Afganistanu, Iraku, Erytrei i Somalii, ale także z Bałkanów (Kosowo, Albania, Serbia, Macedonia) próbowały przedostać się do zamożnych krajów UE w poszukiwaniu schronienia i azylu. Już 7 maja 2015 r. niemiecki minister spraw wewnętrznych Thomas de Maizière oświadczył, że Republika Federalna jeszcze w tym roku może spodziewać się 450 tys. uchodźców z terenów ogarniętych konfliktami i wojną domową. 19 sierpnia skorygowano tę liczbę i podniesiono ją do 800 tys., gdyż dramatycznie zaostrzyła się sytuacja w Syrii, Północnym Iraku i Afganistanie. 25 sierpnia Federalny Urząd ds. Migracji i Uchodźców (BAMF) zadeklarował, że wobec obywateli syryjskich nie będą stosowane unijne regulacje w zakresie azylu i imigracji. Było to następstwem uzgodnień podjętych pomiędzy Angelą Merkel i kanclerzem Austrii Wernerem Faymannem o czasowym zawieszeniu konwencji dublińskiej i przyjęciu azylantów bez rutynowych procedur biurokratycznych. Była to też reakcja na marsz tysięcy migrantów w kierunku Austrii 
z Budapesztu, gdzie od wielu dni koczowali na dworcu kolejowym Keleti. Miała to być jednorazowa akcja spowodowana nadzwyczajną sytuacją i podyktowana względami humanitarnymi. Została jednak odczytana za granicą jako zachęta do masowych przyjazdów przede wszystkim do Niemiec (Hildebrandt, Ulrich, 2015).

Decyzja o otwarciu niemieckiej granicy i zawieszeniu procedury Dublin III wynikła z przesłanki, że zamknięcie granicy niemieckiej stanowiłoby wstęp do rozpadu strefy Schengen i to na RFN jako „mocarstwo środka Europy” spadłaby największa odpowiedzialność. Oznaczałoby to także kapitulację wobec antyeuropejskich populistów i demagogów oraz ich dążeń do rozbicia Unii Europejskiej. Poza tym cofnięcie uchodźczej fali z Austrii i Węgier z powrotem na Bałkany wywołać mogło w słabszych państwach tego regionu - Serbii, Macedonii czy Czarnogórze - konflikty i zaburzenia na niespotykaną skalę (Münkler, 2016, s. 5).

Jeszcze podczas letniej konferencji prasowej w Berlinie 31 sierpnia kanclerz A. Merkel była pełna optymizmu i przekonywała dziennikarzy, że Niemcy sobie poradzą z problemem uchodźców (wir schaffen das!), gdyż są ,silnym państwem” i „stojące przed nimi problemy zostaną przezwyciężone" (Bannas, 2015). Po dodatkowych konsultacjach z premierem Węgier Victorem Orbanem 4 września kanclerz Niemiec złożyła oświadczenie, że uchodźcy nie będą odsyłani i w tej kwestii panuje jedność z partnerem koalicyjnym - SPD.

Nie ulega wątpliwości, że niemiecki optymizm brał się z wieloletnich doświadczeń - tych pozytywnych i negatywnych - związanych z imigracją tysięcy ludzi najpierw do Niemiec Zachodnich, a później po 1990 r. do zjednoczonego państwa. W latach „cudu gospodarczego" już w końcu lat pięćdziesiątych ubiegłego stulecia przy niskim przyroście naturalnym w RFN, niemiecki przemysł wchłaniał każdą liczbę cudzoziemskich pracowników (gastarbeiterów) i w pierwszej kolejności dotyczyło to Turków. Już w 1953 r., pomiędzy Bonn i Ankarą zawarto umowę o wzajemnym zniesieniu wiz. 31 października 1961 r. w Bad Godesberg podpisany został zachodnioniemiecko-turecki układ o czasowym zatrudnianiu pracowników z Turcji na terytorium Republiki Federalnej (wszedł w życie 30 września 1964 r.). Choć w porozumieniu uwzględniani mieli być tylko wolni, młodzi mężczyźni z klauzulą dwuletniej rotacji, to z powodu olbrzymiego zasysania przez niemiecki przemysł siły roboczej, ustalenia te nie były przestrzegane. Lawinowo rosnąca liczba Turków w Niemczech Zachodnich, którzy w zdecydowanej większości zachowywali swoją kulturową i religijną odrębność z czasem stała się uciążliwym balastem, tym bardziej, że koniunktura gospodarcza uległa wyhamowaniu. Już w 1973 r. oficjalnie rząd federalny zamknął werbunek cudzoziemskich robotników nie tylko z Turcji, ale również z Jugosławii, Grecji, Portugalii, Maroka i Tunezji (Hunn, 2005).

Pomimo presji i zachęt finansowych, większość Turków zdecydowała się pozostać w RFN, ściągając rodziny i kładąc podwaliny pod potężną społeczność „niemieckich Turków". Jeżeli w 1961 r. na terytorium RFN przebywało tylko 6800 Turków, to w 2006 r. było już ich 1738 tys., a w 2013 r. 2793 tys. (Migrationsbericht, 2013). Doświadczenia $\mathrm{z}$ ich integracją napawały jednak niepokojem. Badania przeprowadzone przez berliński Institut für Bevölkerung und Entwicklung w 2008 r. wykazały porażkę rządowych programów integracyjnych i uznawały społeczność turecką za najbardziej zamkniętą i niechętną dla procesów asymilacyjnych (Migranten-Studie, 2009). 
Rozpad Jugosławii i wojna w Bośni-Hercegowinie wywołała nową falę emigracji, gdzie Niemcy stały się głównym państwem docelowym. Już w 1992 r. podanie o azyl w tym kraju złożyło 438 tys. osób z terenów objętych walkami. Pomimo zawarcia pokoju w 1995 r. i powolnej stabilizacji sytuacji w tym regionie, według informacji Urzędu Spraw Zagranicznych jeszcze na początku 1997 r. w RFN przebywało 340 tys. osób, głównie Bośniaków, którzy nie palili się do powrotu do ojczyzny. Większości z nich udało się uniknąć deportacji, gdyż kraje związkowe otrzymały wolną rękę co do sposobu i terminu pozbycia się przybyszów z Bałkanów (Koszel, 1999, s. 308-309).

W wyniku kolejnej wojny w Kosowie (1998-1999) na terenie Niemiec znalazło schronienie 55 tys. osób, z czego większość stanowiła ludność romska. Do 2004 r. tylko 5 tys. Kosowian powróciło do kraju. Olbrzymie bezrobocie i brak poczucia stabilności powodowały, że w następnych latach emigracja do Niemiec wzmogła się i do 2014 r. objęła kolejne 9 tys. W styczniu 2015 r. podanie o azyl złożyło 3630 osób pochodzących z tego państwa (Grimmer, 2015).

Zgodnie z danymi Federalnego Urzędu Statystycznego z 3 sierpnia 2015 r. liczba osób o migracyjnym pochodzeniu w ścisłym znaczeniu tego słowa wyniosła w RFN w 2014 r. łącznie 16,4 mln, o 473 tys. więcej niż w 2013 r. Tymczasem ogólna liczba ludności wzrosła o 286 tys., co podniosło ogólną liczbę mieszkańców tego państwa do poziomu $80,897 \mathrm{mln}$. Udział osób o migracyjnym pochodzeniu zwiększył się z 19,7\% do $20,3 \%$. Już rok 2014 był dla imigracji do Niemiec w pewnym sensie przełomowy, ponieważ odnotowano największą liczbę emigrantów od 1992 r. i wyniosła ona 550 tys. Stanowiło to 55\% wszystkich emigrantów w ramach całej Unii Europejskiej (Migrationsbericht, 2015; Wróbel, 2016, s. 47).

Wracając do wydarzeń z lata 2015 r. nietrudno było zauważyć, że optymistyczne prognozy rządu na temat możliwości absorbcyjnych państwa niemieckiego podzieliły niemieckie społeczeństwo. Kanclerz A. Merkel miała silne poparcie w parlamencie, gdyż walka z ksenofobią i otwartość na cudzoziemców zapisana była na sztandarach zarówno Partii Lewicy, jak Zielonych i SPD. Niechętne były pozaparlamentarne ugrupowania: partia Alternatywa dla Niemiec i antyislamska PEGIDA (Patriotyczni Europejczycy przeciw Islamizacji Zachodu). Większe problemy były we własnym obozie politycznym. Nie radząca sobie z koncentracją uchodźców na własnym terenie Bawaria ustami premiera i szefa CSU Horsta Seehofera atakowała liberalną politykę władz i domagała się drastycznych pociągnięć mających ukrócić niekontrolowany napływ osób. Wskazywano, że tylko w ciągu sześciu pierwszych miesięcy 2015 r. ok. 44 tys. Syryjczyków złożyło podanie o azyl w Niemczech, gdyż szybko zorientowali się że niemieckie urzędy nie respektują rozporządzenia Dublin III. W tym samym okresie deportowano do kraju unijnego, który przez potencjalnego azylanta przekroczony został jako pierwszy zaledwie 131 osób (Dublin-Verfahren, 2015).

Z pewnością pochylając się w spektakularny sposób nad uchodźcami, Republika Federalna zyskiwała wizerunkowo w świecie jako kraj wolny od nienawiści rasowej i etnicznych uprzedzeń. Tak więc większa część obywateli opowiadała się za nową „kulturą gościnności” (Wilkommenskultur), choć wiele opiniotwórczych mediów i ekspertów była zadania, że nadmierny napływ uchodźców przerasta zdolności wchłaniania i ,zagospodarowania” uchodźców przez państwo niemieckie. Oponentom wskazywano, że Republika Federalna Niemiec w coraz większym stopniu jest 
konfrontowana z problemami demograficznymi i już obecnie brakuje około jednego miliona rąk do pracy. W XXI w. szczególnie odczuwała skutki szybkiego starzenia się społeczeństwa, stanęła przed koniecznością rozbudowy opieki zdrowotnej i społecznej oraz przygotowania systemu emerytalnego do niezbędnych, dokuczliwych dla przeciętnego obywatela reform, głównie przez podniesienie w 2006 r. granicy przejścia na emeryturę z 65 na 67 lat (Kröhnert, Olst, Klingholz, 2004).

W 1991 r. na terytorium RFN mieszkało 80,274 mln obywateli, z czego 12,032 mln stanowiły osoby powyżej 65 . roku życia. W 2005 r. przy niewielkim przyroście ogólnej liczby mieszkańców $(82,437 \mathrm{mln})$ liczba seniorów powyżej 65 lat znacznie się podniosła i wynosiła już 15870074 (Statistisches Jahrbuch, 2007). W 2010 r. obliczenia pokazywały, że liczba Niemców zmniejszyła się do $81,752 \mathrm{mln}$, a wzrost liczby osób po 65. roku życia nabrał gwałtownego przyspieszenia (16 901 742, a w 2014 r. było to już 20,6\% populacji, czyli 17345234 ) (Statistisches Jahrbuch, 2011).

Działając pod wewnętrzną presją, rząd niemiecki 13 września przywrócił kontrole na granicach, co jednakże zgodne było z regulacjami przewidzianymi $\mathrm{w}$ umowie o ruchu granicznym w ramach Układu z Schengen. Przeprowadzane doraźnie kontrole (wybiórczo wobec samochodów w pasie $20 \mathrm{~km}$ od granicy) tego typu były stosowane również przez Polskę w czasie turnieju Euro 2012 czy przez Niemcy przed ostatnim szczytem państw z grupy G7 w Monachium. Zaostrzone zostało prawo azylowe. 15 października 2015 r. Bundestag przytłaczającą większością (475 głosów za, 68 przeciw i 56 wstrzymujących się) przyjął nowy pakiet ustaw (Asylverfahrensbeschleunigungsgesetz) znacznie ograniczający prawa azylantów do świadczeń społecznych i przyspieszający procedury deportacyjne (Morozowski, 2015).

Im więcej osób przedzierało się do Niemiec i Austrii, tym bardziej zwiększały się niemieckie naciski na sprawiedliwe obciążenie państw unijnych w kwestii relokacji osób szukających schronienia na terenie UE. Po spotkaniu ministrów spraw zagranicznych państw unijnych na podstawie dwóch decyzji Rady z 14 i 22 września ustalono podział 40 tys. i 120 tys. emigrantów przebywających dotąd w Grecji, we Włoszech, bądź w innych państwach dotkniętych kryzysem emigracyjnym. Uwzględniając wyliczone przez Komisję Europejską specjalne współczynniki relokacji uzgodniono, że do Niemiec relokowanych zostanie ponad 40 tys. osób, do Francji - ponad 30 tys., do Hiszpanii - 26 tys., do Polski - około 10-11 tys. Dalsze miejsca w systemie relokacji zajęły Holandia, Rumunia, Belgia, Szwecja, Portugalia, Czechy, Austria, Finlandia, Bułgaria, Słowacja i Chorwacja. Uzgodniono, że najmniej osób przyjmą Litwa, Słowenia, Łotwa, Luksemburg, Estonia, Cypr i Malta. Nie były zainteresowane tym podziałem Dania i Wielka Brytania, Finlandia wstrzymała się od głosu, ale Irlandia wyraziła gotowość przyjęcia 2,9 tys. osób (Potyrała, Wojciechowski, 2015).

Zgodnie z pesymistycznymi ocenami napływ uchodźców do Niemiec na przełomie 2015/2016 r. przerósł najśmielsze oczekiwania i wyniósł 1,1 mln osób. Przekroczyło to możliwości ich zakwaterowania i zaopiekowania się nimi ze strony władz samorządowych i urzędów odpowiedzialnych za opiekę nad przybyszami. Tylko 442899 wniosków znalazło się w procedurze opracowywania. Przybywający thumnie do Niemiec uchodźcy po wstępnych przesłuchaniach byli rozdzielani w ramach specjalnego sytemu elektronicznego „Easy” do poszczególnych krajów związkowych, według z góry ustalonych kwot uchodźczych. Od marca 2015 r. jeżeli przeciągała się procedura 
azylowa otrzymywali oni zasiłek w wysokości 287-359 euro na osobę. Koszty mieszkania, energii i pomocy medycznej również były pokrywane z budżetów lokalnych i dotacji federalnych. Już po 3 miesiącach mogli oni podjąć pracę jeżeli na konkretne stanowisko brakowało Niemca lub obywatela Unii Europejskiej. Po 15 miesiącach pobytu te wstępne ograniczenia były likwidowane (Reimann, 2016).

Wobec tak liberalnego podejścia do problemu uchodźców nie dziwiło, że Niemcy zostały skonfrontowane z masową krytyką płynącą ze stolic europejskich od Aten po Warszawę i Londyn, zwłaszcza, gdy zaczęły twardo się domagać respektowania ustaleń z 14 i 22 września 2015 r. w kwestii rozdziału uchodźców na poszczególne państwa UE. Nie było tajemnicą, że na tym tle doszło do różnicy poglądów pomiędzy niemiecką przywódczynią i przewodniczącym Rady Europejskiej Donaldem Tuskiem.

Obradująca 23 września 2015 r. Rada Europejska na nadzwyczajnym posiedzeniu podjęła pierwsze działania mające ograniczyć skalę zjawiska. Co najmniej dodatkowy jeden miliard euro miał zostać przekazany na pomoc dla uchodźców syryjskich w rejonie Bliskiego Wschodu za pośrednictwem biura Wysokiego Komisarza ONZ ds. uchodźców (UNHCR) i Światowego Programu Żywnościowego, postanowiono zwiększyć pomoc dla Jordanii, Turcji i Libanu. Zapowiadano wzmocnienie kontroli, w tym przez przeznaczenie dodatkowych środków dla agencji Frontex, odpowiedzialnej za ochronę zewnętrznych granic UE, wsparcie finansowe dla Europolu i Europejskiego Urzędu Wsparcia w dziedzinie Azylu (EASO). Podjęte miały zostać prace nad powstaniem tzw. hot spotów w krajach granicznych UE, czyli punktów weryfikacji uchodźców. Miały one pomóc w odróżnieniu uchodźców od imigrantów ekonomicznych (Nieformalne posiedzenie, 2015).

Po następnych spotkaniach szefów rządów i państw unijnych, 17-18 grudnia, Rada Europejska uznała, że realizacja dotychczasowej strategii ,jest niewystarczająca i musi zostać przyspieszona". Aby chronić integralność Schengen, konieczne miało być odzyskanie kontroli nad granicami zewnętrznymi. W konkluzji z posiedzenia postulowano zajęcie się słabymi punktami, w szczególności jeśli chodzi o hot spoty, identyfikację osób, relokację i powroty uchodźców do ojczyzny (Posiedzenie Rady Europejskiej 17 i 18 grudnia 2015 r.).

Od lata 2015 r. w miarę narastania kryzysu związanego z uchodźcami Niemcy na bieżąco prowadzili konsultacje z najbliższym sojusznikiem i partnerem w UE - Francją. Prezydent François Hollande na podstawie doświadczeń francuskich dobrze orientował się jaką niebezpieczną mieszanką wybuchową może być niekontrolowana fala emigrantów i związane z tym problemy. Zamachy terrorystyczne we Francji 13 listopada wskazywały jak trudno sprawować kontrolę nad podejrzanymi osobami. Nie dawał jednak poznać po sobie, że „nadgorliwość” niemiecka wróży nadejście ciężkich czasów dla UE. Opowiedział się za szybkimi działaniami unijnych instytucji dopóki istniała możliwość uporządkowania zjawiska. Mając w perspektywie wybory prezydenckie w $2017 \mathrm{r}$. nie chciał, by ta kwestia napędzała wiatru w żagle Marine Le Pen i Frontowi Narodowemu. Na otwartą krytykę polityki niemieckiej pozwalał sobie natomiast premier Manuel Valls, który w listopadzie 2015 r. i następnie w lutym 2016 r. w wielu publicznych wystapieniach dawał do zrozumienia, że polityka ,gościnności” RFN podkopuje fundamenty UE i Francja z niechęcią odnosi się do proponowanych przez Berlin kwot podziału emigrantów (Frankreich fordert, 2015; Frankreich lehnt, 2016). 
Po intensywnych rozmowach francusko-niemieckich, prezydent Hollande wspólnie z kanclerz Merkel 3 września wystosowali list do przywódców europejskich, szefa Komisji Europejskiej i przewodniczącego Rady Europejskiej. Powołując się na „odpowiedzialność każdego państwa członkowskiego i solidarność wszystkich”, zaapelowali o jak najszybsze wdrożenie programów zatwierdzonych przez Unię Europejska, bronili układu z Schengen z 1985 r., ale największy nacisk położyli na dystrybucję uchodźców „w duchu solidarności między państwami członkowskimi” poprzez utworzenie „stałego mechanizmu i przymusowego przesiedlenia" (Revault d'Allonnes, Stroobants, 2015).

7 października obaj politycy w emocjonalnych przemówieniach do europosłów w Strasburgu przestrzegli, że pogłębienie kryzysu i brak skutecznego przeciwdziałania doprowadzi do zawieszenia strefy Schengen, demontażu polityk wspólnotowych i odejście od euro. Merkel zapowiedziała odejście od starej procedury przyznawania azylu przez państwo unijne którego terytorium przekroczone zostało jako pierwsze, gdyż to nie zdało egzaminu (Réfugiés, 2015).

Na przełomie 2015/2016 r. pole manewru kanclerz Merkel w Unii Europejskiej za sprawą uchodźców zostało znacznie ograniczone. Urzędowe niemieckie dane wskazywały, że w samym listopadzie 2015 r. na terenie Niemiec przyjęto rekordową liczbę wniosków o azyl - 206 tys. i fala uciekinierów wydawała się nie mieć końca. Dwie trzecie podań pochodziło od mężczyzn w wieku 18-35 lat. Biorąc pod uwagę nieścisłości w składaniu danych osobowych, BAMF szacował, że spośród nich jedna szósta uczęszczała na uniwersytety, bądź studiowała w innych szkołach wyższych. 25\% legitymować się miało podstawowym wykształceniem, a 8\% żadnym. Najlepiej wykształceni byli Syryjczycy (Reimann, 2016).

Naciski kanclerz A. Merkel na sprawiedliwe, obowiązkowe rozdysponowanie kwot uchodźców w państwach członkowskich, czy wzmocnienie Frontexu napotykały na opór w większości stolic unijnych, gdyż uważano to za niemiecki szantaż. Premier Węgier Viktor Orban już we wrześniu odrzucił ,imperializm moralny” kanclerz, a przewodniczący Rady Europejskiej Donald Tusk uznał jej politykę migracyjną za „niebezpieczną”. Szef czeskiego rządu Bohuslav Sobotka zarzucił niemieckiej przywódczyni „stymulowanie nielegalnej imigracji”. Z kolei włoski premier Matteo Renzi oskarżył Merkel, że pragnie, aby UE służyła niemieckim interesom. Wysoko dotąd ceniona w rankingach niemieckich za proeuropejską postawę Polska pod rządami Prawa i Sprawiedliwości wystąpiła z szeregów sojuszników Berlina i przyłączyła się do grona ich przeciwników. Liczba zwolenników Niemiec ograniczyła się do Szwecji, Austrii i Komisji Europejskiej. Na początku 2016 r. po zmianie polityki Szwecji wobec uchodźców, grupa wsparcia skurczyła się zaledwie do instytucji unijnych i paraliżowanej przez wzrost notowań Frontu Narodowego Francji (Janning, 2016). Moralnym wsparciem dla osamotnionej niemieckiej przywódczyni był fakt, że renomowana francuska agencja prasowa Agence France Presse uznała ją za najbardziej wpływową osobę w świecie w 2015 r., podobnie zresztą jak amerykański tygodnik „Time” uznając ją za kanclerza wolnego świata.

7 lutego 2016 r. już w zupełnie zmienionych okolicznościach doszło do kolejnych francusko-niemieckich bilateralnych konsultacji w Strasburgu z kurtuazyjnym raczej udziałem przewodniczącego Parlamentu Europejskiego Martina Schulza. Poprzedzić 
one miały wyjazd kanclerz Merkel do Turcji na rozmowy z tamtejszymi politykami. Ze względu na nieradzenie sobie z napływem cudzoziemców do RFN, pozycja kanclerz Merkel zaczęła się chwiać, szczególnie po ekscesach sylwestrowych w Kolonii, co w atakach na rząd wykorzystywały antyemigrancka i ksenofobiczna PEGIDA oraz coraz bardziej się radykalizująca Alternatywa dla Niemiec. Dołującemu w sondażach prezydentowi Hollande'owi szczególnie zależało na jak najszybszemu uregulowaniu kryzysu uchodźczego, co mogłoby powstrzymać jego złe notowania w społeczeństwie. Zgodził się on przyjąć we Francji 30 tys. uchodźców z proponowanej przez UE ogólnej liczby 160 tys. Na niemieckie żądania powiększenia tej kwoty ripostował, że we Francji na rozpatrzenie czeka 80 tys. wniosków azylowych złożonych jeszcze w 2015 r. Za klucz do rozwiązania sytuacji uważał większą pomoc dla Grecji i energiczne włączenie się Turcji do zatrzymania na jej terytorium uchodźczej fali (Boutelet, 2016; Angela Merkel, 2016).

Perspektywa włączenia Turcji - na której terenie w 25 obozach przebywało 2,7 mln uchodźców - do rokowań w sprawie uchodźców była najlepszym rozwiązaniem, ale niemieckiej przywódczyni zaakceptowanie tego faktu przychodziło z dużą trudnością. Kiedy przebywała w Ankarze w połowie października Turcy przedstawili listę żądań, od której realizacji uzależniali swoje zaangażowanie w powstrzymaniu uchodźców napływających do Europy. Widniały na niej wydatna pomoc finansowa na utrzymanie 2,5-2,7 mln Syryjczyków już przebywających w obozach dla uchodźców na terenie Turcji (3 mld euro), jak najszybsze zniesienie wiz do UE dla obywateli tureckich i przyspieszenie rokowań w kwestii akcesji Turcji do UE. Merkel miała świadomość, że trzeba będzie słono zapłacić za turecką pomoc i współdziałanie. Od przejęcia rządów w 2005 r. niemiecka chadecja konsekwentnie podtrzymywała pogląd, że w ,chrześcijańskim klubie" jakim jest UE nie ma miejsca dla muzułmańskiej Turcji, a kanclerz Merkel ofiarowała Ankarze co najwyżej „uprzywilejowane partnerstwo” z UE (Koszel, 2008, s. 131-146). Autorytarne rządy prezydenta Recepa Tayyipa Erdoğana spotykały się z regularną krytyką w Niemczech, a Zieloni i Die Linke ostrzegały kanclerz przed jakimikolwiek koncesjami, które wiązałyby się z akceptacją łamania praw człowieka w tym państwie.

Zaproszony na szczyt Rady Europejskiej w Brukseli 29 listopada 2015 r. premier Turcji Ahmet Davutoğlu miał powody do zadowolenia. Mimo wydanego w tym samym miesiącu, katastrofalnego dla Ankary raportu Komisji Europejskiej w sprawie poszerzenia UE o Turcję, mimo protestów zaplanowanych w Stambule w tym samym dniu w sprawie uwolnienia dwóch uwięzionych dziennikarzy, Unia Europejska z determinacją zabiegała o współpracę z tym państwem w kwestii uchodźców. Pomimo, że prezydent Erdoğan domagał się 7 mld euro, podtrzymała swoje stanowisko o wypłacie Turcji 3 mld euro na pokrycie kosztów transferu Syryjczyków z Grecji i funkcjonowania obozów dla uchodźców na jej terytorium. Pozytywnie odpowiedziano na prośbę o liberalizację wiz dla obywateli tureckich. Komisja Europejska obiecała przyspieszyć prace, aby można było złożyć wniosek o zniesienie krótkoterminowych wiz dla Turków w październiku 2016 r. Propozycja ta była uwarunkowana przyspieszeniem rokowań związanych z umową o readmisji. Do czerwca 2016 r. Turcja musiałaby przyjąć swoich obywateli, którzy nie mają uregulowanego pobytu na terytorium UE. Ankara otrzymała też obietnicę, że sprawa jej akcesu do Unii Europejskiej nabierze teraz 
odpowiedniego przyspieszenia. Odrzucono jednak możliwość rozpoczęcia negocjacji $\mathrm{w}$ pięciu obszarach negocjacyjnych ( $\mathrm{w}$ tym jeden dotyczący wolności, sprawiedliwości i bezpieczeństwie) (Szczyt przywódców UE, 2015; Merelle, 2015).

Krytycznie na ogół postrzegane w Niemczech rozmowy kanclerz z premierem Ahmetem Davutoğlu 7-8 lutego 2016 r. zapowiadały przyspieszenie rokowań z Ankarą w celu uregulowania napływu uchodźców do Europy z terytorium Turcji. Zapowiedziano kontynuowanie transferu syryjskich uciekinierów z Turcji do Europy wraz $\mathrm{z}$ ich rozdzielaniem między poszczególne państwa $\mathrm{w}$ ramach systemu kontyngentowego. Berlin i Ankara opowiedziały się za włączeniem NATO w zwalczanie przemytu ludzi morzem z Turcji do Grecji. Merkel zapowiedziała jednocześnie wzmocnienie wspólnych działań policji niemieckiej i tureckiej w walce z zajmującymi się przemytem ludzi grupami przestępczymi (Merkel verspricht, 2016).

Stopień zaawansowania rozmów z Turcją został pozytywnie oceniony przez Radę Europejską obradującą w Brukseli 18-19 lutego 2016 r. W konkluzjach z obrad szczególnie podkreślono, że ,pełna i szybka realizacja planu działania UE-Turcja nadal ma priorytetowe znaczenie dla powstrzymania przepływów migracyjnych i zwalczania siatek handlarzy i przemytników. Turcja podjęła kroki, by zrealizować ten plan działania, zwłaszcza jeśli chodzi o dostęp syryjskich uchodźców do tureckiego rynku pracy i wymianę danych z UE". Pozytywnie oceniono dotychczasowe działania w zakresie opracowywania wraz z Turcją ,wiarygodnego programu dobrowolnego przyjmowania uchodźców ze względów humanitarnych" (Posiedzenie Rady Europejskiej 18-19 lutego 2016).

18 marca 2016 r. na posiedzeniu Rady Europejskiej z udziałem premiera A. Davatoğlu doszło do sfinalizowania ugody w sprawie uchodźców, której trzon wynegocjowany został w rokowaniach lutowych z kanclerz Merkel. Ze względu na fakt, że tylko w pierwszych dwóch miesiącach 2016 r. 144 tys. osób, w tym połowa Syryjczyków dotarła do Grecji, głównym celem tej umowy było przecięcie drogi i szlaków przemytniczych wiodących przez Morze Egejskie. Turcja złożyła obietnicę, że będzie odbierać od Greków wszystkich migrantów, którzy pokonają Morze Egejskie. Z kolei UE zobowiązała się, że na zasadzie ,jeden za jednego" przeniesie do krajów Unii tylu Syryjczyków (głównie z obozów dla uchodźców w Turcji), ilu odesłanych z Grecji przyjmie Ankara. Ugoda zakładała szybkie przesiedlenie do 72 tys. Syryjczyków. Postanowiono zniechęcić ludzi do opłacania się przemytnikom. Ci, którzy mieliby korzystać z ich usług, straciliby prawo na przesiedlenie się do Unii. Ponadto Ankara - co jeszcze pół roku temu byłoby nie do wyobrażenia - dostała od Brukseli obietnicę zniesienia już w czerwcu wiz dla Turków (po spełnieniu zwykłych warunków). Do 3 mld euro, które UE już wcześniej obiecała na Fundusz Uchodźczy, zgodzono się dorzucić drugie tyle do 2018 r. W ostatniej fazie rokowań najtrudniejszym punktem okazały się żądania Turcji co do ożywienia jej negocjacji członkowskich z UE. Ankara chciała szybkiego otwarcia wspomnianych pięciu rozdziałów negocjacyjnych, które od kilku lat blokował Cypr, m.in. w odwecie za zakaz zawijania jego statków do tureckich portów. Przyjęty kompromis zakładał otwarcie do czerwca 2016 r. tylko jednego rozdziału dotyczącego spraw budżetowych. W Brukseli zapowiedziano prace nad odmrożeniem innych rozdziałów. Obiecano wszechstronne wparcie dla Grecji by wesprzeć jej zdolności „w zakresie organizacji powrotu do Turcji migrantów o nieuregulowanym statusie w kontekście grecko-tureckiego protokołu o readmisji oraz umowy o readmisji UE-Turcja, począwszy od 1 czerwca 2016 r. Państwa członkowskie 
deklarują wolę zapewnienia Grecji w krótkim terminie wszystkich niezbędnych środków, w tym funkcjonariuszy straży granicznej, ekspertów do spraw azylu oraz tłumaczy ustnych" (Konkluzje Rady Europejskiej 17-18 marca 2016; Dobrowolska-Polak, 2016).

Nie ulega wątpliwości, że Unii Europejskiej przyszło zapłacić wysoką cenę za tolerowanie coraz bardziej autorytarnych działań prezydenta Erdoğana. Francja, która uchodziła za zdecydowanie większego przeciwnika obecności tureckiej w UE aniżeli Niemcy, podczas rokowań z Ankarą świadomie trzymała się w cieniu, nie chcąc dawać argumentów populistom z Frontu Narodowego (Merkel-Hollande, 2016). Kanclerz Merkel i jej partyjne zaplecze odnotowało poważne polityczne straty. Dla nieprzejednanych przeciwników łamania praw człowieka w RFN współpraca z prezydentem Erdoğanem to zdrada ideałów i cyniczny handel wartościami. Z drugiej strony rosła presja prawicowych ekstremistów. Dotąd umiarkowana i skupiona na kwestiach gospodarczych, a obecnie radykalizująca się i coraz bardziej demagogiczna i ksenofobiczna Alternatywa dla Niemiec w wyborach do parlamentów krajowych w Nadrenii Palatynacie, Saksonii-Anhalt i Badenii-Wirtembergii 13 marca 2016 r. uzyskała imponujące dwucyfrowe wyniki, będące dla niej dobrą prognozą dla wyborów do Bundestagu w 2017 r. (Kohler, 2016).

Forsując kompleksowe ogólnoeuropejskie rozwiązanie, kanclerz A. Merkel udało się obronić swoją wizję zarządzania kryzysem migracyjnym i dokonać jego europeizacji. Próbowała to jednak robić w stylu, który w wielu krajach uznany został za „moralny szantaż Niemiec". Jak pisał analityk Cornelius Adebahr związany z berlińskim Instytutem DGAP, niewiele wynikało z faktu, że Niemcy postępowali słusznie i po ich stronie były racje etyczne i moralne, skoro nie potrafili do nich przekonać swoich europejskich sojuszników i uzyskać z ich strony poparcia (Adebahr, 2016).

Z pewnością dla Niemiec dużym obciążeniem będą lawinowo rosnące koszty utrzymania uchodźców. Wprawdzie Niemcy posiadają nadwyżkę budżetową, ale szacunki ekonomistów z kolońskiego Instytutu Gospodarki Niemieckiej wskazują, że może ona gwałtownie zmaleć. Obciążenia związane z zapewnieniem im dachu nad głową, wyżywieniem i opieką zdrowotną wyniosły w 2015 r. 5,2 mld euro. Do tego należy dodać sumę około jednego miliarda euro przeznaczoną na sfinansowanie kursów integracyjnych i językowych. Jak się przewiduje, w 2016 r. wydatki zwiększą się o kolejne 22,1 mld euro, a ogólne skumulowane koszty w latach 2015-2017 zamkną się sumą prawie 56 mld euro (Budnikowski, 2016). Jak się jednak wydaje, koszty te zostały wkalkulowane w budżety krajów związkowych, dla których zwiększone zostaną dotacje federalne. Jak wynika $\mathrm{z}$ danych federalnego ministerstwa finansów, każdy z krajów związkowych otrzyma w 2016 r. o 3,7\% więcej wpływów z podatków niż w 2015 r. Oznacza to, zwiększenie budżetów krajowych o średnio 2,8 mld euro. Pomimo przewidywanych obciążeń w Niemczech optymistycznie zakłada się, że przygotowanie nowej infrastruktury technicznej i społecznej dla uchodźców, bazy edukacyjnej, generować będzie nowe miejsca pracy (Balcerek-Kosiarz, 2016).

Przechodząc do ogólnych spostrzeżeń można powiedzieć, że Unia Europejska pod względem rozwiązań prawnych i strukturalnych dobrze jest przygotowana do sprostania wezwaniom polityki imigracyjnej. Jednakże istniejące zapisy i regulacje w dużym stopniu funkcjonują tylko na papierze. Problemem i największą bolączką jest brak konsensu wśród państw członkowskich, gdzie niektóre z nich nie będąc bezpośred- 
nio dotknięte tym zjawiskiem, jak np. Grecja czy Włochy, nie posiadają elementarnego zrozumienia dla koniecznej w tym wypadku europejskiej solidarności i ujawniają o różnej skali natężenia narodowe egoizmy.

\section{Bibliografia}

Adebahr C. (2016), Die Flüchtlingskrise zwingt uns, die Welt neu zu verstehen, „DGAPstandpunkt”, $\mathrm{nr}$ 2, https://dgap.org/de/think-tank/publikationen/dgapstandpunkt/mehr-aussenpolitik.

Angela Merkel et François Hollande réaffirment une «ligne commune» sur les réfugiés (2016), „Le Monde" z 8.02.2016.

Balcerek-Kosiarz M. (2016), Ryzyko wzrostu zadtużenia krajów zwiazkowych i gmin z powodu kryzysu uchodźców w Niemczech, „Biuletyn Instytutu Zachodniego”, nr 232, http://www.iz.poznan.pl/news/1409_232_uchodzcy_zadluzenie_Niemcy.pdf.

Bannas G. (2015), Merkel: ,, Wir schaffen das”, „Frankfurter Allgemeine Zeitung” z 31.08.2015.

Boutelet C. (2016), La crise des réfugiés bouscule Hollande et Merkel, „Le Monde” z 8.02.2016.

Budnikowski T. (2016), Republika Federalna Niemiec: rosnace koszty napływu uchodźców, „Biuletyn Instytutu Zachodniego", nr 228.

Die Generation 65+ in Deutschland (2015), Statistisches Bundesamt, Wiesbaden, https://www. destatis.de/DE/PresseService/Presse/Pressekonferenzen/2015/generation65/Pressebroschuere_generation65.pdf?_blob=publicationFile.

Dobrowolska-Polak J. (2016), Turcja, Unia Europejska i uchodźcy. Porozumienia w sprawie zarzadzania kryzysem migracyjnym, „Biuletyn Instytutu Zachodniego”, nr 229, http://www. iz.poznan.pl/news/1398_229_Turcja_UE_uchodzcy.pdf.

Dublin-Verfahren ausgesetzt: Syrien-Flüchtlinge dürfen in Deutschland bleiben (2015), „Der Spiegel” z 25.08.2015.

Europejski Pakt o Imigracji i Azylu. Rada Europejska, 24 września 2008, http://register.consilium. europa.eu/doc/srv?l=PL\&f=ST\%2013440\%202008\%20INIT.

Frankreich fordert Aufnahmestopp für Flüchtlinge (2015), „Frankfurter Allgemeine Zeitung” $\mathrm{z} 25.11 .2015$.

Frankreich lehnt EU-Flüchtlingskontingente ab (2016), „Die Zeit” z 13.02.2016.

Gebauer M., Salloum R. (2015), Flüchtlinge: Warum jetzt so viele Menschen kommen, „Der Spiegel” z 9.09.2015.

Grimmer C. (2015), Da war doch was?, BR 24, http://www.br.de/nachrichten/fluechtlinge-rueckblick-kosovo-balkan-100.html.

Gruszczak A. (red.) (2010), Program Sztokholmski - implikacje i wyzwania dla Unii Europejskiej i Polski, Centrum Europejskie Natolin, http://www.natolin.edu.pl/pdf/mat-rob/CEN_MatRob_16.pdf.

Hildebrandt T., Ulrich B. (2015), Im Auge des Orkans, „Die Zeit” z 20.09.2015.

Hunn K. (2005), „Nächstes Jahr kehren wir zurück...” Die Geschichte der türkischen „, Gastarbeiter" in der Bundesrepublik, Wallstein Verlag, Göttingen.

Janning J. (2016), Germany - Europe's lonely leader, European Council on Foreign Relations, http:// www.ecfr.eu/article/germany_europes_lonely_leader5061.

Kohler B. (2016), Merkels Verdienst und Verantwortung, „Frankfurter Allgemeine Zeitung” z 18.03.2016.

Konkluzje Rady Europejskiej (17-18 marca 2016), http://www.consilium.europa.eu/pl/press/pressreleases/2016/03/18-european-council-conclusions/.

Koszel B. (1999), Mitteleuropa rediviva? Europa Środkowo i Poludniowo-Wschodnia w polityce zjednoczonych Niemiec, Wyd. Instytutu Zachodniego, Poznań. 
Koszel B. (2008), ,,Uprzywilejowane partnerstwo”. Rzqd Angeli Merkel (CDU/CSU-FDP) wobec integracji Turcji z Unia Europejska, „Rocznik Integracji Europejskiej”, nr 2.

Kröhnert S., Olst van N., Klingholz R. (2004), Deutschland 2010. Die demographische Zukunft der Nation, http://www.berlin-institut.org/fileadmin/user_upload/Studien/D_2020_Webversion.pdf.

Merelle L. (2015), UE-Turquie: les heures de gloire de Davutoglu et Erdogan, „Le Point” z 30.11.2015.

Merkel verspricht der Türkei Flüchtlingskontingente (2016), „Die Zeit” z 8.02.2016.

Merkel-Hollande: un tandem à deux vitesses (2016), „Le Figaro” z 18.03.2016.

Migranten-Studie: Türken sind mit Abstand am schlechtesten integriert (2009), „Der Spiegel” z 24.01.2009.

Migrationsbericht des Bundesamtes für Migration und Flüchtlinge im Auftrag der Bundesregierung Migrationsbericht (2012), http://www.bamf.de/SharedDocs/Anlagen/DE/Publikationen/Migrationsberichte/migrationsbericht-2012.pdf?_blob=publicationFile.

Migrationsbericht des Bundesamtes für Migration und Flüchtlinge im Auftrag der Bundesregierung. Migrationsbericht (2014), http://www.bamf.de/SharedDocs/Anlagen/DE/Publikationen/Migrationsberichte/migrationsbericht-2014.html?nn=1663558.

Morozowski T. (2015), Zmiany legislacyjne w Niemczech $w$ obliczu kryzysu uchodźczego, „Biuletyn Instytutu Zachodniego", nr 192, http://www.iz.poznan.pl/uploads/pracownicy/morozowski/1244_niemieckie_prawo_uchodzcy.pdf.

Münckler H. (2016), Die Mitte und die Flüchtlingskrise: Über Humanität, Geopolitik und innenpolitische Folgen der Aufnahmeentscheidung, „Aus Politik und Zeitgeschichte”, nr 14-15.

Nieformalne posiedzenie szefów państw i rzq̨ów (2015), 23.9.2015, Rada Europejska, http://consilium.eu.int/pl/meetings/european-council/2015/09/23/.

Posiedzenie Rady Europejskiej (17 i 18 grudnia 2015 r.) - Konkluzje, www.consilium.europa.eu/p1/ meetings/european-council/2015/12/17/18.

Posiedzenie Rady Europejskiej 18-19 lutego 2016 - konkluzje, www.consilium.europa.eu/pl/meetings/european-council/2016/02/18-19/.

Posiedzenie Rady Europejskiej w Tampere 15-16 października 1999 r. Wnioski prezydencji, http:// www.cie.gov.pl/HLP/mointintgr.nsf/0/4B14EBAFF4B0DC80C1256E75005617A8/\$file/ ME5326A.pdf.

Potyrała A., Wojciechowski S. (2015), ,Za” $i$,,przeciw”. Unijny dwugłos w sprawie systemu relokacji, „Biuletyn Instytutu Zachodniego”, nr 192, http://www.rgib.org.pl/images/stories/dokumenty/2015/pazdziernik/Unijny_dwuglos.pdf.

Program haski: wzmacnianie wolności, bezpieczeństwa i sprawiedliwości w Unii Europejskiej, Dz. U. UE 2005, Nr C 53/13, http://eur-lex.europa.eu/LexUriServ/LexUriServ.do?uri=O$\mathrm{J}: \mathrm{C}: 2005: 053: 0001: 0014: P L: P D F$.

Program sztokholmski - otwarta i bezpieczna Europa dla dobra i ochrony obywateli, Dz. U. UE 2010, Nr C 115/1 z 4.05.2010, http://eur-lex.europa.eu/LexUriServ/LexUriServ.do?uri= OJ:C:2010:115:0001:0038:pl:PDF.

Réfugiés: pour Hollande et Merkel «sans unité, c'est la fin de l'Europe (2015), „Le Parisien” z 7.10.2015.

Reimann A. (2016), Endlich verständlich: Fakten zur Flüchtlingskrise, „Der Spiegel” z 10.05.2016.

Revault d'Allonnes D., Stroobants J.-P. (2015), La lettre commune de François Hollande et d'Angela Merkel pour accueillir les réfugiés en Europe, „Le Monde” z 4.09.2015.

Rozporządzenie Parlamentu Europejskiego i Rady (UE) nr 604/2013 z dnia 26 czerwca 2013 r. w sprawie ustanowienia kryteriów i mechanizmów ustalania państwa członkowskiego odpowiedzialnego za rozpatrzenie wniosku o udzielenie ochrony międzynarodowej złożonego 
$w$ jednym z państw czlonkowskich przez obywatela państwa trzeciego lub bezpaństwowca (2013), http://eur-lex.europa.eu/legalcontent/PL/TXT/?uri=URISERV:2.

Statistisches Jahrbuch 2007 für die Bundesrepublik Deutschland, https://www.destatis.de/DE/Publikationen/StatistischesJahrbuch/Jahrbuch2007.pdf?_blob=publicationFile.

Statistisches Jahrbuch 2011. Für die Bundesrepublik Deutschland mit internationalen Übersichten, http://www.bv-agrar.de/bvagrar/agrarwelt/daten/destatis/StatistischesJahrbuch2011.pdf.

Szczyt przywódców UE z Turcja, 29.11.2015 - Oświadczenie UE-Turcja, http://m.european-council. europa.eu/pl/press/press-releases/2015/11/29-eu-turkey-meeting-statement/.

Unia radzi o bezpieczeństwie (2016), „Gazeta Wyborcza” z 25.03.2016.

Wróbel I. (2016), W kierunku kultury powitania. Reforma polityki prawa Republiki Federalnej Niemiec $w$ dziedzinie imigracji, „Przegląd Zachodni”, $\mathrm{nr} 1$.

Wspólny Europejski System Azylowy (2014), http://ec.europa.eu/dgs/home-affairs/e-library/docs/ceas-fact-sheets/ceas_factsheet_pl.pdf.

\section{Streszczenie}

Artykuł analizuje politykę Unii Europejskiej wobec uchodźców i azylantów, koncentrując się przede wszystkim na latach 2014-2016. Autor pokazuje, że kluczową rolę w kryzysie związanym z uchodźcami odegrali Niemcy, przyjmując na swoje terytorium bez żadnych warunków wstępnych tysiące ludzi. W związku z trudnościami, które wystąpiły z tego powodu, Niemcy próbowały narzucić przymusowy podział uchodźców na poszczególne państwa Unii Europejskiej, co wywołało wewnętrzny kryzys w tej organizacji. Dopiero dzięki współpracy z Turcją kryzys uchodźczy udało się opanować, ale Unia Europejska potrzebuje zdecydowanej polityki w tym zakresie, bo dotychczasowe rozwiązania nie zdają egzaminu.

Słowa kluczowe: Unia Europejska, Niemcy, problem uchodźców

\section{The European Union, Germany and the issue of refugees (2014-2016)}

\section{Summary}

The article analyzes the European Union's policy towards refugees and asylum seekers, focusing primarily on 2014-2016. The author shows that a key role in the crisis related to refugees played by Germany, accepting on its territory without any preconditions thousands of people. In connection with the difficulties that have occurred for this reason, Germany tried to impose mandatory allocation of refugees on the individual Member States of the European Union, which has triggered an internal crisis in the organization. Only through cooperation with Turkey refugee crisis it was brought under control, but the European Union needs a strong policy in this regard, because the old solutions existing solutions do not appear.

Key words: European Union, Germany, refugee problem 